\title{
Fatty Acid Profile and Anti-Inflammatory Activity of Fixed Plant Oils
}

\author{
Selene Maia de Morais ${ }^{1,2}$, José Eranildo Teles do Nascimento ${ }^{2}$, Antonio Adailson de Sousa Silva ${ }^{3}$, \\ José Eduardo Ribeiro Honório Junior ${ }^{4}$, Diana Célia Sousa Nunes Pinheiro² \& Ricardo Vasconcelos de Oliveira ${ }^{5}$
}

\begin{abstract}
Background: Many seed oils have been used as anti-inflammatory agents, administred by ingestion or topical application in traditional medicine. The objective of this research was to perform a chemical analysis of fatty profile and a pharmacological study through a topical experiment of TPA-induced ear edema test and an internal assay - acetic acid-induced vascular permeability in Swiss mice of some fixed oils popularly used for inflammatory problems, trying to confirm their action.

Materials, Methods \& Results: Fixed lipids of Ouratea fieldingiana (batiputá), Caryocar coreaceum (pequi), Annacardium occidentale (cashew-nuts), Cocos nucifera (coco-da-bahia), Byrsonima crassifolia (murici) e Elaeis guineenses (palm) were selected for the identification of fatty acids profile by gas chromatography coupled to mass spectrometry (GC/MS) analysis and evaluation of anti-inflammatory activity by TPA-induced ear edema test and acetic acid-induced vascular permeability in Swiss male mice. The oils were purchased in local markets or extracted in Soxhlet apparatus with hexane. The oils of cashew nut, murici fruit, and pequi nut presented a high percentage of unsaturated fatty acids $(81.80,74.46$ and $60.72 \%$, respectively). In the oils of batiputá and murici, linoleic acid was the main unsaturated fatty acid (45.06\% and $74.66 \%$, respectively) and oleic acid was main constituent in cashew nut, pequi and palm seed oils. Batiputá and palm oils exibit approximately equivalent content of saturated and unsaturated fatty acid and coconut oil more saturated fatty acids $(80.72 \%)$ with predominance of lauric acid. The result of TPA-induced ear edema test revealed that all oils presented similar anti-inflammatory activity. In the acetic acid-induced vascular permeability model, the oil of $O$. fieldingiana was the only one who showed anti-inflammatory activity, while C. coreaceum and B. crassifolia oils showed pro-inflammatory activities. The presence of phenols and flavonoids was evaluated in the $O$. fieldingiana oil by spectrophometric methods.

Discussion: All the oils showed anti-inflammatory action in the TPA-induced ear edema, probably the action of unsaturated fatty acids was more important in topical application, nevertheless in internal inflammation process the presence of antioxidant phenolic compounds could contribute to the higher activity of the oil from $O$. fieldingiana. The effect of linoleic and oleic acids was demonstrated on the inflammatory response of the skin during the healing process and on the release of pro-inflammatory cytokines by rat neutrophils in a prevoius study using sunflower oil. Both oleic and linoleic acids increased the wound healing tissue mass. The total protein and DNA contents of the wounds were increased by the treatment with linoleic acid. This pro-inflammatory effect of oleic and linoleic acids may contribute to the wound healing process. In this study with six plant oils, some of them have higher content in linoleic acid and others oleic acid is the major constituent so the antiinflamatory action on ear edema can be associated to these two unsaturaded fatty acids mechanism of action. In the internal model, probably other chemical constituents revealed in Ouratea fieldingiana as phenols, condensed tannins, flavones and flavanones, could contribute to the anti-inflammatory activity.
\end{abstract}

Keywords: phytotherapy, fixed oils, inflammation. 


\section{INTRODUCTION}

The use of herbal medicine with anti-inflammatory action has been increased in recent years with the search for active principles that play effective role in this process. Some seed oils displays anti-inflammatory properties administred by ingestion or topical application, such as sunflower oil (Helianthus annus), which is used frequently as anti-inflammatory, antiseptic and healing agent [1].

Some other fixed oil extracts have been also employed to treat inflammation and among them the following species are in Northeastern Brazil: Ouratea fieldingiana popularly known as Batiputá [18]; Caryocar coreaceum, which yields a fruit common known as Pequi, used widely in Araripe, southern Ceará and the fixed oil has been employed in the treatment of skin inflammation, respiratory affections [7], wound healing and muscle pain; Byrsonima crassifolia fruit oil showed anti-inflammatory action in a pharmacological study $[10,16]$; Anacardium occidentale, popularly known as cashew, has a great economic importance in Brazil and cashew nut is one of the main exportation products [6]; Cocus nucifera (coconut) kernel and tender coconut water have numerous medicinal properties such as antibacterial, antifungal, antiviral, antiparasitic, antidermatophytic, antioxidant, hypoglycemic, hepatoprotective, immunostimulant [13,14]; Elaeis guineensis, common name palm, in the Amazon region, is widely used in the treatment of wounds and inflammations [2].

This study aimed to characterize the fatty acid profile and evaluate the anti-inflammatory activity of seed oils of $O$. fieldingiana, B. crassifolia, $C$. nucifera, A. occidentale, C. coreaceum and E. guineensis.

\section{MATERIALS AND METHODS}

\section{Plant identification}

The plants were identified and their voucher specimens deposited in the Herbarium Prisco Bezerra of the Federal University of Ceará. The herbarium specimens of the plants were deposited with the number 27698 and to Ouratea fieldingiana, 23178 to Caryocar coriaceum. The kernels of A. occidentale were obtained at the Brazilian Agricultural Research Corporation - EMBRAPA.

\section{Obtaining of seed oils}

The fruits of $C$. coreaceum were acquired in the Cariri. The seeds were exposed to dry for 10 days.
Subsequently, the nuts were removed manually and were then crushed with a homemade multiprocessor. The fruits of Byrsonima crassifolia, and the oil from the seeds of Cocos nucifera were acquired in Fortaleza, CE, Brazil markets. The seeds of B. crassifolia were placed to dry and then crushed mechanically. The crude oil of $O$. fieldingiana was obtained in the trade city of Cascavel. The oil from seeds of B. crassifolia and $C$. coreaceum was extracted according to the Folch method. After being crushed almonds oil was extracted with chloroform and methanol at a ratio of 2:1 v/v for 25 $\mathrm{h}$, then saturated $\mathrm{NaCl}$ solution was added to facilitate separation of the organic phase containing the lipids, of the aqueous phase. The organic phase was evaporated to give oil. The oil of almonds of Annacardium occidentale was extracted through SOXLHET apparatus.

\section{Phytochemical analysis of batiputa seed oil}

Chemical tests were performed following the protocols described by Matos [11], based on reactions with specific reagents for the main classes of natural products with precipitate formation or color change. The content of phenolic compounds were determined by spectrophometric (Helios Biomate) ${ }^{1}$ methods of Folin-Ciocalteu reagent for total phenols [19] and $\mathrm{AlCl}_{3}$ reagent for flavonoids [5].

\section{Preparation of methyl esters}

Prior to analysis, samples of crude oil from each plant were subjected to a transesterification reaction where fatty acids were converted into methyl esters. This technique consists of mixing $0.5 \mathrm{~g}$ of oil with 5 $\mathrm{mL}$ of hexane and $5 \mathrm{~mL}$ of $0.1 \mathrm{M} \mathrm{KOH}$ in methanol $^{2}$, in $20 \mathrm{~cm}$ glass test tubes with screw caps, with subsequent heating in a water bath at $50^{\circ} \mathrm{C}$ for one hour. Thereafter were added $4 \mathrm{~mL}$ of hexane and $15 \mathrm{~mL}$ of $5 \% \mathrm{HCl}$ in a separatory funnel, from which the hexane phase was collected, containing the methyl esters.

\section{Fatty analysis by GC / MS}

The analysis of methyl esters of fatty acids of oil was performed using a gas chromatograph coupled to a mass spectrometer (Hewlett-Packard GC/MS model 5971A) ${ }^{3}$ equipped with a capillary column of $25 \mathrm{~mm} \times 0.25 \mathrm{~mm}$ methyl - silicon and silica fused, using helium as the carrier gas. The temperature program was from 50 to $180^{\circ} \mathrm{C}$, increasing $10^{\circ} / \mathrm{min}$. The identification of the constituents was made by looking at the computer, retention index and interpretation of 
fatty acids in each sample library, along with their percentages in order of volatility.

Animals

Female Swiss albino mice weighing $25 \mathrm{~g}$ were obtained from the Central Animal Laboratory of the Federal University of Ceará - UFC. The animals were fed a standard commercial diet and given water and food ad libitum. The animals were kept under normal conditions of humidity, temperature and light (cycles of $12 \mathrm{~h}$ light and $12 \mathrm{~h}$ in the dark). The mice were randomly assigned to the control group and the other treatment groups, being ten animals per group.

The in vivo experiments obeyed the rules of handling laboratory animals, established by the Brazilian College of Animal Experimentation (COBEA) and the experimental protocols were approved by the Christus University ethics committee for the use of animals with the number 013/25.

Acetic acid-induced vascular permeability in mice

This test consists in evaluating the extravasation of fluid into the peritoneal cavity through the direct estimation of plasma-dye absorption, measured by spectrophotometer1. To perform the experiment, 7 groups of animals were formed, and each group contained 6 animals. The group of animals, which only received treatment with acetic acid, was called negative control group. Another group consisted of animals treated with indomethacin ${ }^{4}$ (reference drug) positive control. The other groups were treated for each vegetable oil studied.

The separate groups of mice received injections of $100 \mu \mathrm{L}$ oil intraperitoneally at the beginning of the experiment. Thirty min after the injection of oils, each animal received via the retro-orbital plexus, $100 \mu \mathrm{L}$ of saline solution of Evans blue $\mathrm{e}^{4} 1 \%$. Ten min after administration of the dye, $400 \mu \mathrm{L}$ of $0.5 \%$ acetic acid solution was injected intraperitoneally. Twenty min after injection of acetic acid, the animals were sacrificed and its intraperitoneal cavity was exposed and irrigated with $10 \mathrm{~mL}$ of distilled water. The volume recovered was placed in $10 \mathrm{~mL}$ test tubes. To each tube $100 \mathrm{~mL}$ of $1 \mathrm{~N} \mathrm{NaOH}$ solution was added to eliminate the turbidity caused by proteins. The reference group was treated with indomethacin $(10 \mathrm{mg} / \mathrm{kg})$ orally.

The samples were analyzed for absorbance values in a spectrophotometer using a wavelength of $590 \mathrm{~nm}$. The standard curve was obtained from a stan- dard solution of 1.0\% Evans blue and several dilutions were prepared: $3.9,7.8,15.6,31.3,62.5,125,250$ and $500 \mathrm{mg} / \mathrm{mL}$.

The results were expressed in mg of Evans blue extravazed (average) and standard deviation of the experimental groups.

\section{TPA-induced ear edema test}

The 12-O-tetradecanoylphorbol 13-acetate (TPA $)^{4}$ is an irritant used in cutaneous inflammation model in mice ears. The topical application of TPA induces inflammation and hyperproliferative responses (when used chronically) in animals, resembling in many respects the signs of some skin diseases such as psoriasis [12].

The animals were divided into groups of 10 and received in right and left ear, topical application of 2.5 $\mu \mathrm{g}$ of TPA in acetone solution $(0.125 \mu \mathrm{g} / \mu \mathrm{L}), 10 \mu \mathrm{L}$ for each ear. Treatment consisted of topical application of $20 \mu \mathrm{L}$ of vegetable oil administered to the right ear (10 $\mu \mathrm{L}$ for each ear) immediately after TPA treatment. The left ears were treated with TPA and only were used as controls. Indomethacin was used as reference drug $(0.5$ $\mathrm{mg}$ /ear). After $4 \mathrm{~h}$ the animals were sacrificed by cervical dislocation. $5.0 \mathrm{~mm}$ diameter discs were removed from each ear and the weight was determined. Edema was measured by the difference between the weights of the discs of the right and left ears, and expressed as the increase in ear thickness.

\section{RESULTS}

The relative percentage composition of the fatty acids of the studied plants is shown in Table 1. The fixed oils of cashew nut, murici fruit, and pequi nut presented a high percentage of unsaturated fatty acids $(81.80,74.46$ and $60.72 \%$, respectively). In the oils of batiputá and murici, linoleic acid was the main unsaturated fatty acid with $45.06 \%$ and $74.66 \%$, respectively and oleic acid was main constituent in cashew nut oil. Batiputá and palm oils exibit approximately equivalence between saturated and unsaturated fatty acid content and coconut oil more saturated fatty acids $(80.72 \%)$.

In the test of acetic acid-induced vascular permeability in mice, the group of animals that received acetic acid intraperitoneally was considered the negative control group. This group showed 75.35 $\pm 7.64 \mu \mathrm{g}$ of dye. Indomethacin used as the reference drug, showed a decrease in leakage of fluid from the 
abdominal cavity in the order of $29.12 \pm 2.19 \mu \mathrm{g}$. All results are displayed in table 2.

The leakage of liquid found in the treatment with coconut oil was $84.50 \pm 21.44 \mu \mathrm{g}$, with the cashew oil was $101.25 \pm 14.87 \mu \mathrm{g}$ and the palm oil $105.00 \pm$ 22. $44 \mu \mathrm{g}$. The effect of Pequi and Murici seed oils was $129.62 \pm 33.69 \mu \mathrm{g}$ and $161.25 \pm 38.67 \mu \mathrm{g}$ respectively, values well above that found in the group of untreated animals.

Only batiputá oil showed similar statistical results to indomethacin $(37.43 \pm 5.83 \mu \mathrm{g})$. The oil presented a 1:1 proportion between unsaturated and saturated fatty acids. Phenolic compounds were detected, which also could be responsible for the anti-inflammatory action. Phytochemical tests of the $O$. fieldingiana oil revealed the presence of phenols, condensed tannins, flavones and flavanones, being determined total phenol as $11.6 \pm 2.29 \mathrm{mgEAG} / \mathrm{g}$ extract and flavonoid content was $9.51 \pm 0.071 \mathrm{mgEQ} / \mathrm{g}$ extract.

In the ear edema test, after $4 \mathrm{~h}$ of treatment, the group of animals that did not receive any treatment (negative control) presented a swelling which increased the weight of the discs from mice ears of $6.26 \pm 0.17$ $\mathrm{mg}$ and the weight in the group of animals whose ears received only TPA (positive control - CP) was 14.70 $\pm 1.30 \mathrm{mg}$ (Table 3 ). Indomethacin, used as reference drug, reduced the edema caused by the irritant to 6.80 $\pm 0.70 \mathrm{mg}$ (approximately $50 \%$ of the edema formed) and presented statistically similar results to the group of untreated animals.

Table 1. Percentage composition of fatty acids methyl esters of fixed oil extracted from plant seeds.

\begin{tabular}{|c|c|c|c|c|c|c|}
\hline $\begin{array}{c}\text { Plant / } \\
\text { Fatty Acid }\end{array}$ & Batiputá & Pequi & Murici & Cashew nut & Coconut & Palm \\
\hline Capric & - & - & - & - & 3.84 & - \\
\hline Lauric & 0.56 & - & - & - & 41.9 & - \\
\hline Myristic & 2.57 & - & - & - & 17.22 & 1.16 \\
\hline Palmitic & 33.64 & 16.08 & 16.66 & 8.27 & 10.10 & 36.61 \\
\hline Palmitoleic & 1.45 & - & - & - & - & - \\
\hline Stearic & 11.76 & 22.18 & 8.88 & 9.93 & 7.65 & 5.13 \\
\hline Oleic & 4.88 & 34.52 & - & 81.80 & 19.28 & 55.95 \\
\hline Linoleic & 45.06 & - & 74.66 & - & - & - \\
\hline $\boldsymbol{\alpha}$-Linolenic & - & 26.20 & - & - & - & - \\
\hline Arachidonic & - & 1.02 & - & - & - & - \\
\hline Saturated FA & 49.98 & 39.28 & 25.54 & 18.20 & 80.72 & 44.05 \\
\hline Unsaturated FA & 49.94 & 60.72 & 74.46 & 81.80 & 19.28 & 55.95 \\
\hline
\end{tabular}

The fatty acid methyl esters are displayed in order of elution from a non-polar column of the gas chromatograph. FA = Fatty Acid. 
Table 2. Evaluation of the extravasation of fluid into the peritoneal cavity through the direct estimation of plasma-dye absorption measured by spectrophotometer to compare the effect of plant seed oils on vascular permeability in mice induced by acetic acid.

\begin{tabular}{cc}
\hline Treatment & Extravasation of dye $(\mu \mathrm{g}) \mathrm{X} \pm \mathrm{SD}$ \\
\hline Negative control group (acetic acid) & $75.35 \pm 7.64^{\mathrm{a}}$ \\
Indomethacin & $29.12 \pm 2.19^{\mathrm{b}}$ \\
Batiputá oil & $37.43 \pm 5.83^{\mathrm{b}}$ \\
Cashew nut oil & $101.25 \pm 14.87^{\mathrm{c}}$ \\
Coconut oil & $84.50 \pm 21.44^{\mathrm{a}, \mathrm{c}}$ \\
Dendê oil & $105.00 \pm 22.44^{\mathrm{c}}$ \\
Murici oil & $161.25 \pm 38.67^{\mathrm{d}}$ \\
Pequi oil & $129.62 \pm 33.69^{\mathrm{c}, \mathrm{d}}$ \\
\hline
\end{tabular}

Values are expressed as mean \pm standard deviation; $n=6$. Different letters means statistical significant differences

Table 3. Anti-inflammatory effect of the oils on the ear edema induced by 12-O-tetradecanoylphorbol 13 -acetate (TPA).

\begin{tabular}{ccc}
\hline Treatment & $\begin{array}{c}\text { Edema }(\mathrm{mg}) \\
\mathrm{X} \pm \mathrm{SD}\end{array}$ & Inhibition $(\%)$ \\
\hline TPA & $6.26 \pm 0.17^{\mathrm{a}}$ & - \\
Indomethacin & $14.70 \pm 1.3^{\mathrm{b}}$ & - \\
Batiputá oil & $6.80 \pm 0.7^{\mathrm{a}}$ & 53.75 \\
Coconut oil & $9.33 \pm 1.57^{\mathrm{a}}$ & 36.54 \\
Cashew nut oil & $6.16 \pm 0.47^{\mathrm{a}}$ & 58.1 \\
Dendê oil & $8.92 \pm 0.83^{\mathrm{a}}$ & 39.29 \\
Murici oil & $6.66 \pm 0.58^{\mathrm{a}}$ & 54.7 \\
Pequi oil & $8.60 \pm 0.85^{\mathrm{a}}$ & 41.5 \\
\hline Results are expressed as mean \pm standard deviation, $\mathrm{n}=10 ;(P<0,05)$. Different letters means statistical \\
significant differences
\end{tabular}

\section{DISCUSSION}

In the test of acetic acid-induced vascular permeability in mice, it was found that the liquid leaking found in the treatment with coconut oil, cashew nut oil and palm oil were statistically similar to that found in the group of untreated animals, demonstrating that these oils had no effect on the extravasation of fluid into the abdominal cavity of animals. The effect of seed oils of Pequi and Murici were higher than that found in the untreated animals. The plasma protein extravasation caused after use of these oils was greater than that made by the group of animals treated with acetic acid by intraperitoneal via, showing pro-inflammatory action.

Only batiputá oil showed similar statistical results to indomethacin. The fatty acid profile of Batiputá oil presented a 1:1 proportion between unsaturated and saturated fatty acids and a high content of linoleic acid, similarly to other oils. Probably the differences in the fatty acid profile are not responsible for its higher activity in this internal inflammation model. Local population obtains this oil by seeds extraction with boiling water, then separating the oil 
by decantation. Probably this procedure facilitates the incorporation of phenolic compounds in the oil, which contribute to the antioxidant protection to tissues of abdominal cavity. As antioxidants have shown antiphlogistic properties and attenuate tissue lesion [3], the phenolic composition of the oil from the batiputa oil might be involved in the attenuation of the inflammatory process.

A pharmacological study revealed that $C$. coreaceum fixed oil (CCFO) was able to reduce the edema and the influx of inflammatory cells in mice ears sensitized with Croton oil and Arachidonic acid, indicating the potential application of $\mathrm{CCFO}$ as an important herbal medicine to be used against skin inflammatory diseases $[8,17]$. In this study, the inflammation was caused by TPA and the healing action of pequi oil corroborates those previous studies using other inflammatory agents.

In Brazilian traditional medicine, Ouratea spp. have been indicated for the treatment of palsy, erysipelas and uterine wounds. Leaves of $O$. spectabilis are used as stomachic and vermifuge, as well as for the treatment of gastric distress. Leaf infusions of $O$. parviflora have long been prescribed for the treatment of inflammation-related diseases such as rheumatism, sprains and arthritic disorders, and further skin diseases [4,20,21]. In this study $O$. fieldingiana oil gave positive results in ear edema tests confirming the use of the plant for skin diseases, similarly to other oils of this study.

The skin injury causes a series of events including inflammation, new tissue formation, and tissue remodeling, which finally lead to at least partial reconstruction of the wounded area. The repair process is initiated immediately after injury by the release of various growth factors, cytokines, and low-molecular weight compounds from the serum of injured blood vessels [22].

In the ear edema test, all oils studied were able to decrease the swelling in relation to the group of animals receiving TPA. A previous work showed by morphometrical, clinical and histological assays that sunflower-seed oil improved the granulation tissue formation and epithelial resurfacing of wounds. The authors stated that sunflower-seed oil or other vegetable oils containing a high concentration of linoleic acid can be indicated as a therapeutic al- ternative for wound healing process in veterinary medicine [9].

The effect of linoleic and oleic acids was demonstrated on the inflammatory response of the skin during the healing process and on the release of pro-inflammatory cytokines by rat neutrophils. A wound in the dorsal surface of adult rats was performed and fatty acids were then topically administered. Both oleic and linoleic acids increased the wound healing tissue mass. The total protein and DNA contents of the wounds were increased by the treatment with linoleic acid [15]. This proinflammatory effect of oleic and linoleic acids may speed up the wound healing process [22]. In this study with 6 plant oils, some of them have higher content in linoleic acid and others oleic acid is the major constituent so the anti-inflamatory action on ear edema can be associated to these two unsaturaded fatty acids mechanism of action.

\section{CONCLUSIONS}

All oils presented similar activity in topical application on ear-edema test showing probably a balance between oleic and linoleic acid contribution in the anti-inflammatory action. In the acetic acid-induced vascular permeability model, the oil of Ouratea fieldingiana was the only one who showed anti-inflammatory activity, while Caryocar coreaceum and Byrsonima crassifolia oils showed pro-inflammatory actions. In the internal model, probably other chemical constituents revealed in Ouratea fieldingiana as phenols, condensed tannins, flavones and flavanones, could contribute to the antiinflammatory activity.

\section{MANUFACTURERS}

${ }^{1}$ Thermo Fisher Scientific inc. Suffolk, UK.

${ }^{2}$ Vetec Química Fina Ltda. Duque de Caxias, RJ, Brazil.

${ }^{3}$ Hewlett Packard Enterprise. Palo Alto, CA, USA.

${ }^{4}$ Sigma Aldrich. Darmstadt, Germany.

Ethical approval. The in vivo experiments obeyed the rules of handling laboratory animals, established by the Brazilian College of Animal Experimentation (COBEA) and the experimental protocols were approved by the ethics committee for the use of the University Center Christus animals with the number 013/25, Ceua-Unichristus 013/25.

Declaration of interest. The authors declare no conflicts of interest. The authors alone are responsible for the content and writing of paper. 


\section{REFERENCES}

1 Camurça-Vasconcelos A.L.F., Morais S.M., Santos L.F.L., Rocha M.F.G. \& Bevilaqua C.M.L. 2005. Validação de plantas medicinais com atividade anti-helmíntica. Revista Brasileira de Plantas Medicinais. 7: 97-106.

2 Carvalho A.V., Alves B.J.R. \& Reis V.M. 2006. Resposta do dendezeiro à adição de nitrogênio e sua influência na população de bactérias diazotróficas. Pesquisa Agropecuária Brasileira. 41(2): 293-300.

3 Cuzzocrea S., Riley D.P., Caputi A.P. \& Salvemini D. 2001. Antioxidant therapy: a new pharmacological approach in shock, inflammation, and ischemia/reperfusion injury. Pharmacological Review. 53: 135-159.

4 Fidelis Q.C., Ribeiro T.A.N., Araújo M.F. \& Carvalho M.G. 2014. Ouratea genus: chemical and pharmacological aspects. Revista Brasileira de Farmacognosia. 24: 1-19.

5 Funari C.S. \& Ferro V. 2006. Análise de Própolis. Ciência e Tecnologia de Alimentos, Campinas. 26: 171-178.

6 Guissoni A.C.P., Silva I.G., Geris R., Cunha L.C. \& Silva H.H.G. 2013. Atividade Larvicida de Anacardium occidentale Como Alternativa ao Controle de Aedes aegypti e Sua Toxicidade em Rattus norvegicus. Revista Brasileira de Plantas Medicinais. 15(3): 363-367.

7 Kubo I., Muroi H \& Himejima M. 1993. Structure - Antibacterial activity relationships of anacardic acids. Journal of Agricultural and Food Chemistry. 41: 1016-1019.

8 Lima A., Silva A.M.O., Trindade R.A., Torres R.P. \& Mancini-Filho J. 2007. Composição Química e Compostos Bioativos Presentes na Polpa e na Amêndoa do Pequi (Caryocar brasiliense, Camb.). Revista Brasileira de Fruticultura. 29(3): 695-698.

9 Marques S.R., Peixoto C.A., Messias J.B., Albuquerque A.R. \& Silva Junior V.A. 2004. The effects of topical application of sunflower-seed oil on open wound healing in lambs. Acta Cirúrgica Brasileira. 19(3): 196-209.

10 Martinez-Vasques A.R.M., Gonzales-Esquinca L., Cazares L.M., Gutiérrez N.M. \& Garcia-Argaez A.N. 1999. Antimicrobial Activity of Byrsonima crassifolia (L.) H.B.K. Journal of Ethnopharmacology. 66: 79-82.

11 Matos F.J.A. 2004. Constituintes químicos ativos e propriedades biológicas de plantas medicinais brasileiras. Fortaleza: Editora UFC, 448p.

12 Medeiros K.C.P., Monteiro J.C., Diniz M.F.F.M., Medeiros I.A., Silva B.A. \& Piuvezam M.R. 2007. Effect of the activity of the Brazilian polyherbal formulation: Eucalyptus globulus Labill, Peltodon radicans Pohl and Schinus terebinthifolius Radd in infl ammatory models. Revista Brasileira de Farmacognosia. 17(1): 23-28.

13 Oliveiros L.B., Vedela A.M., Ramirez D.C. \& Gimenez M.S. 2003. Dietary fat saturation produces lipid modifications in peritoneal macrophages of mouse. Journal of Nutritional Biochemistry. 14: 370-377.

14 Oliveira M.S.C., Morais S.M., Magalhães D.V., Batista W.P., Vieira I.G.P., Craveiro A.A., Menezes J.E.S.A., Carvalho A.F.U. \& Lima G.P.G. 2010. Antioxidant, larvicidal and antiacetylcholinesterase activities of cashew nut shell liquid constituents. Acta Tropica. 117: 165-116.

15 Pereira L.M., Hatanaka E., Martins E.F., Oliveira F., Liberti E.A., Farsky S.H., Curi R. \& Pithon-Curi T.C. 2008. Effect of oleic and linoleic acids on the inflammatory phase of wound healing in rats. Cell Biochemistry and Function. 26(2): 197-204.

16 Rezende C.M. \& Fraga S.R.G. 2003. Chemical and aroma determination of the pulp and seeds of murici (Byrsonima crassifolia L.). Journal of Brazilian Chemical Society. 14(3): 425-428.

17 Saraiva R.A., Araruna M.K., Oliveira R.C., Menezes K.D., Leite G.O., Kerntopf M.R., Costa J.G., Rocha J.B., Tomé A.R., Campos A.R. \& Menezes I.R. 2011. Topical anti-inflammatory effect of Caryocar coriaceum Wittm. (Caryocaraceae) fruit pulp fixed oil on mice ear edema induced by different irritant agentes. Journal of Ethnopharmacology. 136: 504-510.

18 Singh S., Nair V., Jain S. \& Gupta Y.K. 2008. Evaluation of anti-inflammatory activity of plant lipids containing alpha-linolenic acid. Indian Journal of Experimental Biology. 46(6): 453-456.

19 Sousa C.M., Silva H.R.E., Vieira-Jr G.M., Ayres M.C.C., Costa C.L.S., Araújo D.S., Cavalcante L.C.D., Barros E.D.S., Araújo P.B.M., Brandão M.S. \& Chaves M.H. 2007. Fenóis totais e atividade antioxidante de cinco plantas medicinais. Quimica Nova. 30: 351-355. 
20 Suzart L.R., Daniel J.F.S., Carvalho M.G. \& Kaplan M.A.C. 2007. Biodiversidade flavonoídica e aspectos farmacológicos em espécies dos gêneros Ouratea e Luxemburgia (Ochnaceae). Química Nova. 30: 984-987.

21 Velandia J.R., Carvalho M.G., Braz Filho R. \& Werle A.A. 2002. Biflavonoids and a glucopyranoside derivative from Ouratea semiserrata. Phytochemical Analysis. 13: 283-292.

22. Werner S. \& Grose R. 2003. Regulation of Wound Healing by Growth Factors and Cytokines. Physiological Reviews. 83: $85-870$. 